\title{
TrpC3/C7 and Slo2.1 Are Molecular Targets for Metabotropic Glutamate Receptor Signaling in Rat Striatal Cholinergic Interneurons
}

\author{
Allison P. Berg, ${ }^{1}$ Neil Sen, ${ }^{1}$ and Douglas A. Bayliss ${ }^{1,2}$ \\ Departments of ${ }^{1}$ Pharmacology and ${ }^{2}$ Anesthesiology, University of Virginia, Charlottesville, Virginia 22908
}

\begin{abstract}
Large aspiny cholinergic interneurons provide the sole source of striatal acetylcholine, a neurotransmitter critical for basal ganglia function; these tonically active interneurons receive excitatory inputs from corticostriatal glutamatergic afferents that act, in part, via metabotropic glutamate receptors ( $\mathrm{mGluRs}$ ). We combined electrophysiological recordings in brain slices with molecular neuroanatomy to identify distinct ion channel targets for $\mathrm{mGluR} 1 / 5$ receptors in striatal cholinergic interneurons: transient receptor potential channel 3/7 (TrpC3/C7) and Slo2.1. In recordings obtained with methanesulfonate-based internal solutions, we found an mGluR-activated current with voltage-dependent and pharmacological properties reminiscent of $\operatorname{TrpC} 3$ and TrpC7; expression of these TrpC subunits in cholinergic interneurons was verified by combined immunohistochemistry and in situ hybridization, and modulation of both TrpC channels was reconstituted in HEK293 (human embryonic kidney 293) cells cotransfected with mGluR1 or mGluR5. With a chloridebased internal solution, mGluR agonists did not activate interneuron TrpC-like currents. Instead, a time-dependent, outwardly rectifying $\mathrm{K}^{+}$current developed after whole-cell access, and this $\mathrm{Cl}^{-}$-activated $\mathrm{K}^{+}$current was strongly inhibited by volatile anesthetics and mGluR activation. This modulation was recapitulated in cells transfected with Slo2.1, a Na ${ }^{+}$- and $\mathrm{Cl}^{-}$-activated $\mathrm{K}^{+}$channel, and Slo2.1 expression was confirmed histochemically in striatal cholinergic interneurons. By using gramicidin perforated-patch recordings, we established that the predominant agonist-activated current was $\operatorname{TrpC}$-like when ambient intracellular chloride was preserved, although a small $\mathrm{K}^{+}$current contribution was observed in some cells. Together, our data indicate that mGluR1/5-mediated glutamatergic excitation of cholinergic interneurons is primarily a result of activation of $\operatorname{TrpC} 3 / \operatorname{TrpC} 7-$ like cationic channels; under conditions when intracellular $\mathrm{NaCl}$ is elevated, a Slo2.1 background $\mathrm{K}^{+}$channel may also contribute.
\end{abstract}

Key words: mGluR; TrpC; Slo2; striatum; interneurons; basal ganglia

\section{Introduction}

The striatum is the primary input nucleus of the basal ganglia system, receiving and integrating afferent dopaminergic inputs from the substantia nigra and glutamatergic inputs from the cortex (Conn et al., 2005). Among the abundant GABAergic medium spiny output neurons within the striatum, four types of histochemically distinct local interneurons have been identified (Kawaguchi et al., 1995). Of these cells, the large aspiny cholinergic interneurons provide the sole source of striatal acetylcholine (ACh). An appropriate balance between dopaminergic and cholinergic drive is essential for normal basal ganglia activity, and therefore, control of interneuron membrane excitability and cholinergic tone is of fundamental importance in the regulation of striatal function (Calabresi et al., 2000a). Indeed, it has recently been established that dynamic modulation of cholinergic inter-

\footnotetext{
Received Feb. 7, 2007; revised July 2, 2007; accepted July 2, 2007.

This work was supported by National Institutes of Health Grants F31 NS50982 (A.P.B.) and NS33583 (D.A.B.). We thank Drs. Y. Mori, C. Montell, S. Ikeda, G. Milligan, and L. Kaczmarek for generous gifts of TrpC, mGluR1/5, H1 histamine receptor, and Slo2 channel constructs, and Michaela Levin for her contribution with Slo2.2 recordings. Correspondence should be addressed to Allison P. Berg at her present address: Feinberg School of Medicine, Northwestern University, 303 East Chicago Avenue, Chicago, IL 60611-3008. E-mail: a-berg@northwestern.edu. DOI:10.1523/JNEUROSCI.0551-07.2007

Copyright $\odot 2007$ Society for Neuroscience $\quad 0270-6474 / 07 / 278845-12 \$ 15.00 / 0$
}

neurons is crucial for synaptic plasticity in the striatum, which is implicated in reward-related learning. For example, increased ACh release plays a permissive role in long-term potentiation at corticostriatal synapses on medium spiny neurons (Centonze et al., 1999); in contrast, long-term depression at those synapses requires decreased ACh release associated with a dopamineinduced pause in interneuron firing (Calabresi et al., 1997; Wang et al., 2006).

Tonically active cholinergic interneurons display a number of intrinsic firing patterns (Bennett et al., 2000) that are determined by complex interactions between voltage-dependent ion channels and influenced by actions of various neuromodulators. Corticostriatal glutamatergic afferents provide a principal excitatory input to striatal neurons, mediating their effects via ionotropic and three classes of metabotropic glutamate receptors (mGluRs) (Conn et al., 2005). Of relevance here, striatal cholinergic interneurons express both of the group I mGluRs, mGluR1 and mGluR5 (Conn and Pin, 1997). Previous studies have demonstrated that activation of mGluR1 and mGluR5 in striatal cholinergic interneurons leads to membrane depolarization, increased neuronal excitability, and ACh release (Takeshita et al., 1996; Marti et al., 2001; Bell et al., 2002). Conflicting results from different studies suggest that mGluR activation causes inhibition of 
a background $\mathrm{K}^{+}$current (Takeshita et al., 1996; Calabresi et al., 1999; Bonsi et al., 2005), activation of an unidentified inward current, or both (Bell et al., 2002); the molecular basis for these mGluR-sensitive currents has not been determined.

In this study, we used patch-clamp recording in brain slices to demonstrate that group 1 mGluRs modulate the activity of two distinctly different types of ionic currents in large striatal interneurons: transient mixed-cationic currents with voltage dependence and pharmacological properties of transient receptor potential channel 3 (TrpC3) and TrpC7 channels (Trebak et al., 2007); and a Cl${ }^{-}$-activated background $\mathrm{K}^{+}$current reminiscent of Slo2.1 (Bhattacharjee and Kaczmarek, 2005). Modulation of these channels was reconstituted in human embryonic kidney 293 (HEK293) cells coexpressing mGluR1/5 receptors with either TrpC3/TrpC7 or Slo2.1 channels. We used in situ hybridization and immunohistochemistry to show definitively that these specific TrpC subunits and Slo2.1 channels are expressed in striatal cholinergic interneurons. Interestingly, the prevalent ionic mechanism in interneurons was dependent on intracellular chloride concentration $\left(\left[\mathrm{Cl}^{-}\right]_{\mathrm{i}}\right)$; with elevated $\left[\mathrm{Cl}^{-}\right]_{\mathrm{i}}$, Slo2.1-like $\mathrm{Cl}^{-}$-activated $\mathrm{K}^{+}$channels represented the predominant mGluR-sensitive target, whereas TrpC-like channels were primarily responsible for mGluR-activated currents under low ambient $\left[\mathrm{Cl}^{-}\right]_{\mathrm{i}}$.

\section{Materials and Methods}

All animal use was in accordance with guidelines approved by the University of Virginia Animal Care and Use Committee.

\section{DNA expression constructs}

Channel constructs and receptor cDNAs were obtained as follows: pCIneo-mTrpC3 and pCIneo-mTrpC7 from Y. Mori (Kyoto University, Kyoto, Japan); pcDNA3-hTrpC6 from C. Montell (Johns Hopkins University, Baltimore, MD); pcDNA3.1-mGluR1a and pRK5-mGluR5a from S. Ikeda (National Institutes of Health, Bethesda, MD); Histamine H1-pcDNA3 from G. Milligan (University of Glasgow, Glasgow, UK); and pTracer-rSlo2.1 (Slick) and pTracer-rSlo2.2 (Slack) from L. Kaczmarek (Yale University, New Haven, CT). The Slo2.1 and Slo2.2 constructs were subcloned into pcDNA3 and, for electrophysiological recordings in HEK293 cells, a green fluorescent protein (GFP)-Slick fusion protein was made by QuikChange PCR insertion of GFP at the N terminus of pcDNA3-Slick (Geiser et al., 2001); these constructs were verified by sequencing.

\section{In situ hybridization}

Probes. Isotopic in situ hybridization and nonisotopic in situ hybridization combined with immunohistochemistry were performed as described previously (Talley et al., 2001; Berg and Bayliss, 2007). Ion channel constructs (TrpC3, TrpC6, TrpC7, Slo2.1, and Slo2.2) were linearized at either the $5^{\prime}$ or $3^{\prime}$ end of the coding regions by restriction digest. Multiple probes that matched different parts of Slo2.2 were generated by PCR to account for different isoforms of Slo2.2 (Bhattacharjee and Kaczmarek, 2005); striatal expression patterns for Slo2.2 were the same for all template sequences. In vitro transcription was performed on linearized templates using either digoxigenin-11-UTP (Roche, Indianapolis, IN) or $\alpha-\left[{ }^{33} \mathrm{P}\right] \mathrm{UTP}$ in labeling reactions with an appropriate RNA polymerase to yield probes in sense and antisense orientations (T7, T3 or SP6; Promega, Madison, WI). Digoxigenin-labeled riboprobes were purified on ProbeQuant G-50 Microcolumns (GE Healthcare, Piscataway, NJ). Radiolabeled probes were purified by ethanol precipitation, quantified by scintillation counting, and used for hybridization at a final concentration of $\sim 1 \times 10^{8} \mathrm{cpm} / \mathrm{ml}$.

Nonisotopic in situ hybridization combined with immunohistochemistry. Sprague Dawley rats [postnatal day 10 (P10) to P18] were perfused transcardially with heparin-containing saline and then $4 \%$ paraformaldehyde (PFA) in phosphate buffer, $\mathrm{pH}$ 7.4. The brains were removed, postfixed overnight in $4 \% \mathrm{PFA}$, and cut $(30 \mu \mathrm{m})$ on a vibrating microtome
(VT1000S; Leica, Bannockburn, IL). Sections were stored at $-20^{\circ} \mathrm{C}$ in cryoprotectant (30\% RNase free sucrose, $30 \%$ ethylene glycol, $1 \%$ polyvinylpyrrolidone, and $100 \mathrm{~mm}$ sodium phosphate, $\mathrm{pH}$ 7.4).

For hybridization with nonisotopic probes, sections were rinsed in sterile PBS and placed, free-floating, into prehybridization mixture (0.6 м NaCl, 0.1 м Tris-Cl, pH 7.5, 0.002 м EDTA, 0.05\% NaPPi, 0.5 mg/ml yeast total RNA, $0.05 \mathrm{mg} / \mathrm{ml}$ yeast tRNA, $1 \times$ Denhardt's BSA, $50 \%$ formamide, $10 \%$ dextran sulfate, $0.05 \mathrm{mg} / \mathrm{ml}$ oligo-dA, $10 \mu \mathrm{M}$ of the four deoxynucleoside triphosphates, $0.5 \mathrm{mg} / \mathrm{ml}$ herring sperm DNA, and 10 mм DTT) at room temperature for $30 \mathrm{~min}$ and then at $37^{\circ} \mathrm{C}$ for $1 \mathrm{~h}$. Digoxigenin-labeled probes were added directly to the prehybridization solution, and sections were incubated at $55-60^{\circ} \mathrm{C}$ for $16-20 \mathrm{~h}$. Sections were rinsed through decreasing concentrations of salt solutions, treated with RNase $\mathrm{A}$ at $37^{\circ} \mathrm{C}$, and then subjected to a final high-stringency wash $\left(0.1 \times \mathrm{SSC}\right.$ at $55^{\circ} \mathrm{C}$ for $60 \mathrm{~min} ; 1 \times \mathrm{SSC}: 150 \mathrm{~mm} \mathrm{NaCl}$ and $15 \mathrm{~mm}$ sodium citrate, $\mathrm{pH}$ 7).

For immunostaining after hybridization, sections were incubated in blocking solution $(0.1 \%$ Triton X-100, 10\% horse serum, and $100 \mathrm{~mm}$ Tris-buffered saline) for $30 \mathrm{~min}$. Immunochemical detection of digoxigenin and choline acetyltransferase (ChAT) was achieved by incubating sections with alkaline phosphatase-conjugated sheep anti-digoxigenin antibody (1:1000; Roche) and goat anti-ChAT (1:100; Millipore, Billerica, MA) for $36-48 \mathrm{~h}$ at $4^{\circ} \mathrm{C}$. After rinsing, alkaline phosphatase was reacted with nitroblue tetrazolium and 5-bromo-4-chloro-3-indolylphosphate, 4-toluidine salt in colorization buffer $\left(50 \mathrm{mM} \mathrm{MgCl}_{2}, 100 \mathrm{~mm}\right.$ Tris, $\mathrm{pH} 9.5$, and $100 \mathrm{~mm} \mathrm{NaCl}$ ) while protected from light. The reaction was quenched by rinsing in $10 \mathrm{~mm}$ Tris and $1 \mathrm{~mm}$ EDTA, $\mathrm{pH} 8.5$, before sections were incubated for $1 \mathrm{~h}$ with Cy3-conjugated anti-goat antibody (1:400; Jackson ImmunoResearch, West Grove, PA).

Isotopic in situ hybridization. Brains from Sprague Dawley rats (P10 to P18) were removed and rapidly frozen on dry ice. Sections $(10 \mu \mathrm{m})$ were cut in a cryostat (Reichert Jung CM3000), thaw mounted onto charged slides (Superfrost Plus; Fisher Scientific, Houston, TX), and stored at $-80^{\circ} \mathrm{C}$ until use. Sections were fixed briefly ( $5 \mathrm{~min}$ ) in $4 \%$ PFA, rinsed repeatedly in PBS, treated successively with glycine $(0.2 \%$ in PBS) and acetic anhydride $(0.25 \%$ in $0.1 \mathrm{M}$ triethanolamine and $0.9 \%$ saline, $\mathrm{pH} 8$ ), and dehydrated in a graded series of ethanols and chloroform. Hybridization was performed overnight at $60^{\circ} \mathrm{C}$ in a buffer of $50 \%$ formamide, $4 \times$ SSC, $1 \times$ Denhardt's solution $(0.02 \%$ each of Ficoll, polyvinylpyrrolidone, and bovine serum albumin), 10\% dextran sulfate, 100 mM DTT, $250 \mu \mathrm{g} / \mathrm{ml}$ yeast tRNA, and $0.5 \mathrm{mg} / \mathrm{ml}$ salmon testes DNA. After hybridization, slides were washed through two changes of $4 \times$ SSC (30 min each), treated with RNase A at $37^{\circ} \mathrm{C}(50 \mu \mathrm{g} / \mathrm{ml}$ for $30 \mathrm{~min})$, washed again through two changes each of $2 \times$ SSC and $0.5 \times$ SSC ( 20 min each), and finally subjected to a high-stringency wash of $0.1 \times$ SSC (30 min). All washes were performed at $37^{\circ} \mathrm{C}$ and included $10 \mathrm{~mm}$ sodium thiosulfate, with the exception of the high-stringency wash, which was performed at $62.5^{\circ} \mathrm{C}$ without sodium thiosulfate.

Data analysis and image capturing. Slides were exposed to film (Amersham Hyperfilm $\beta$-Max; GE Healthcare) for 5-7 d. The resulting autoradiographs were mounted on a light box and imaged using a Retiga 1300 CCD camera (QImaging, Surrey, British Columbia, Canada) and IPLab software (BioVision, Exton, PA). For resolution of cellular labeling from isotopic in situ hybridization, slides were dipped in Kodak (Rochester, NY) NTB2 liquid autoradiographic emulsion and exposed for 3-6 weeks. Emulsion-dipped slides and immunostained sections were examined by dark-field, bright-field, and fluorescence microscopy using a Zeiss (Thornwood, NY) Axioskop 2 microscope and images obtained with a Retiga 1300 camera and IPLab.

\section{Cellular electrophysiology}

Cell culture and transfections. HEK293T cells were maintained in DMEM/ F-12 containing $10 \% \mathrm{FBS}$, penicillin $(100 \mathrm{U} / \mathrm{ml})$, and streptomycin $(100$ $\mu \mathrm{g} / \mathrm{ml})$ and supplemented with G418 (400 $\mu \mathrm{g} / \mathrm{ml}$; Invitrogen, Carlsbad, CA). For experiments with mGluR receptors, cells were switched to DMEM without L-glutamine before transfection. Cells were transfected using LipofectAMINE 2000 (Invitrogen), according to the manufacturer's instructions. Cells were plated onto poly-L-lysine $(100 \mu \mathrm{g} / \mathrm{ml})$ - 
coated coverslips $\sim 12-16 \mathrm{~h}$ after transfection and allowed to adhere for $30 \mathrm{~min}$ at $37^{\circ} \mathrm{C}$ before recording.

Brain slice preparation. Whole-cell recording from neurons in brain slices was performed as described previously (Berg and Bayliss, 2007). Rats (P10-P18) were anesthetized with ketamine/xylazine and rapidly decapitated. The forebrain was removed, blocked, and glued to the stage of a microslicer (DSK 1500E; Dosaka, Kyoto, Japan), and striatal slices were cut $(300 \mu \mathrm{m})$ while immersed in ice-cold substituted Ringer's solution consisting of the following (in $\mathrm{mM}$ ): 260 sucrose, $3 \mathrm{KCl}, 5 \mathrm{MgCl}_{2}$, $1 \mathrm{CaCl}_{2}, 1.25 \mathrm{NaH}_{2} \mathrm{PO}_{4}, 26 \mathrm{NaHCO}_{3}, 10$ glucose, and 1 kynurenic acid. Slices were incubated for $1 \mathrm{~h}$ at $37^{\circ} \mathrm{C}$ and subsequently at room temperature in normal Ringer's solution containing the following (in mM): 130 $\mathrm{NaCl}, 3 \mathrm{KCl}, 2 \mathrm{MgCl}_{2}, 2 \mathrm{CaCl}_{2}, 1.25 \mathrm{NaH}_{2} \mathrm{PO}_{4}, 26 \mathrm{NaHCO}_{3}$, and 10 glucose. Substituted and normal Ringer's solutions were bubbled with $95 \% \mathrm{O}_{2} / 5 \% \mathrm{CO}_{2}$.

Whole-cell recording. Slices were placed in a tissue chamber on a Zeiss Axioskop FS microscope and visualized with infrared differential interference contrast (IR-DIC) microscopy; cholinergic interneurons were identified in the neostriatum based on their distinctive morphology (large neurons, $\sim 20-50 \mu \mathrm{m}$ in diameter) (Calabresi et al., 2000a). Recordings were performed at room temperature using Sylgard-coated borosilicate glass pipette capillaries (3-5 M $\Omega$ ). A number of different pipette solutions were used in these experiments. A standard K-methane sulfonate $\left(\mathrm{KMeSO}_{3}\right)$-based solution contained the following (in $\mathrm{mM}$ ): $120 \mathrm{KCH}_{3} \mathrm{SO}_{3}, 4 \mathrm{NaCl}, 1 \mathrm{MgCl}_{2}, 0.5 \mathrm{CaCl}_{2}, 10$ HEPES, 10 EGTA, $3 \mathrm{ATP}$, and 0.3 GTP; a $\mathrm{CsMeSO}_{3}$-based internal was identical except that 30 tetraethylammonium- $\mathrm{Cl}$ and $100 \mathrm{CsCH}_{3} \mathrm{SO}_{3}$ were substituted for 120 $\mathrm{KCH}_{3} \mathrm{SO}_{3}$; a KCl-based internal contained the following (in $\mathrm{mM}$ ): 115 $\mathrm{KCl}, 5 \mathrm{MgCl}_{2}, 10 \mathrm{CaCl}_{2}, 5$ HEPES, 20 BAPTA, $3 \mathrm{ATP}$, and $0.3 \mathrm{GTP}$; a $\mathrm{Cl}^{-}$-free internal solution of otherwise identical composition was made by substituting $\mathrm{KMeSO}_{3}$ equimolar for $\mathrm{Cl}^{-}$and by using $\mathrm{Mg}(\mathrm{OH})_{2}$ and $\mathrm{Ca}(\mathrm{OH})_{2}$ in place of $\mathrm{MgCl}_{2}$ and $\mathrm{CaCl}_{2}$; for current-clamp recordings, we used the following (in $\mathrm{mm}$ ): $17.5 \mathrm{KCl}, 122.5 \mathrm{~K}$-gluconate, $9 \mathrm{NaCl}, 1$ $\mathrm{MgCl}_{2}$, 10 HEPES, 0.2 EGTA, 3 ATP, and $0.3 \mathrm{GTP}$; for recording from GFP-Slick-transfected cells, we used the pipette solution described previously (Bhattacharjee et al., 2003) (in mM): $130 \mathrm{KCl}, 5$ EGTA, 10 HEPES, 3 ATP, and 0.3 GTP. For perforated-patch recordings, we included gramicidin at $65 \mu \mathrm{g} / \mathrm{ml}$ in the standard $\mathrm{KMeSO}_{3}$-based internal solution (prepared by sonication from a $10 \mathrm{mg} / \mathrm{ml}$ stock in DMSO and used within $2 \mathrm{~h}$; Sigma-Aldrich, St. Louis, MO) and used capillary glass without filaments.

For recording from striatal interneurons and transfected cells, bath solution contained the following (in mM): $140 \mathrm{NaCl}, 3 \mathrm{KCl}, 10$ HEPES, 10 glucose, $2 \mathrm{CaCl}_{2}$, and $2 \mathrm{MgCl}_{2}$ for all experiments. To block $I_{\mathrm{h}}$, the pipette or bath solution contained $50 \mu \mathrm{M}$ 4-ethylphenylamino-1,2-dimethyl-6methylaminopyrimidinium chloride (ZD7288). We added tetrodotoxin (TTX; $0.5 \mu \mathrm{M}$ ) to block action potentials and included glibenclamide (10 $\mu \mathrm{M})$ and barium $(200 \mu \mathrm{M})$ to block $\mathrm{K}_{\mathrm{ATP}}$ and Kir channels. Where indicated, we replaced $\mathrm{NaCl}$ in the bath solution with Tris- $\mathrm{HCl}$, and cadmium $(250 \mu \mathrm{M})$ was included to block voltage-gated $\mathrm{Ca}^{2+}$ channels. For current-clamp experiments, TTX was excluded from the bath solution described above, and we included $10 \mu \mathrm{M}$ bicuculline, $30 \mu \mathrm{M}$ strychnine, and $10 \mu \mathrm{M}$ CNQX. Anesthetic sensitivity of native currents and cloned channels was tested by bubbling isoflurane (1.9\%) into the bath solution through a calibrated vaporizer.

Drugs used in experiments were as follows: 3,5-dihydroxyphenylglycine (3,5-DHPG), 2-methyl-6-(phenylethynyl)pyridine (MPEP) hydrochloride, and ZD7288 from Tocris Bioscience (Ellisville, MO); flufenamic acid (FFA), gadolinium chloride, histamine dihydrochloride, 7-(hydroxyimino)cyclopropan[b]chromen- $1 \alpha$-carboxylic acid ethyl ester (CPCCOEt), and lanthanum chloride from Sigma-Aldrich; and TTX from Alomone Labs (Jerusalem, Israel).

Data acquisition and analysis. Voltage commands were applied and currents recorded using pCLAMP software interfaced with an Axopatch 200A amplifier via a Digidata 1322A digitizer (all from Molecular Devices, Union City, CA). Series resistance was compensated by $60-75 \%$ and monitored throughout the recordings to ensure adequate compensation. Neurons were held at $-60 \mathrm{mV}$ and either hyperpolarized (from -60 to $-130 \mathrm{mV}$ ) or depolarized (from -120 to $+60 \mathrm{mV}$ ) by voltage ramp protocols as indicated in Results and figure legends. Transfected HEK293T cells were held at $-60 \mathrm{mV}$, and depolarizing ramps (from -130 to $+20 \mathrm{mV}$ for Slo2 channels; from -120 to $+60 \mathrm{mV}$ for TrpC channels) were applied at $5 \mathrm{~s}$ intervals. For analysis, slope conductance was evaluated by linear fits to currents from -60 to $-80 \mathrm{mV}$ for neurons and -85 to $-35 \mathrm{mV}$ for HEK293T cells expressing Slo2 channels. Values are expressed as averages $\pm \mathrm{SE}$, and statistical comparisons were by $t$ test and ANOVA, with $p<0.05$ considered significant.

\section{Results \\ Group I mGluRs increase excitability of striatal cholinergic interneurons via two ionic mechanisms}

To elucidate the molecular basis for glutamate excitation of striatal cholinergic interneurons, we recorded from directly visualized large aspiny neurons in a rat brain slice preparation. Under IR-DIC optics, presumptive cholinergic interneurons were easily recognized in the slice as infrequently encountered large cells $(20-50 \mu \mathrm{m})$ intermingled with the more plentiful and smaller $(10-18 \mu \mathrm{m})$ medium spiny GABAergic projection neurons (Fig. $1 A)$. Under voltage clamp, these large neurons presented properties characteristic of cholinergic interneurons, including strong instantaneous and time-dependent inward rectification (reflecting an inwardly rectifying $\mathrm{K}^{+}$current along with a hyperpolarization-activated cationic current) and a prominent A-type $\mathrm{K}^{+}$current that was evident during depolarization from hyperpolarized potentials (data not shown) (Song et al., 1998; Wilson, 2005). In separate studies, we found that the overwhelming majority of striatal neurons identified via these morphological and electrophysiological characteristics were indeed cholinergic (Berg and Bayliss, 2007). As expected, activation of mGluR1/5 receptors with a selective agonist (3,5-DHPG; 100 $\mu \mathrm{M})$ in large striatal interneurons caused rapid membrane depolarization associated with a burst of firing that was followed by a sustained increase in firing activity (Fig. $1 B$ ).

We used whole-cell voltage clamp to characterize currents evoked by mGluR1/5 receptor activation and found that two distinct ionic mechanisms contributed to mGluR-sensitive currents; the prevalent mechanism depended on recording conditions. As shown in Figure 1C, we consistently found that 3,5-DHPG (50 $\mu \mathrm{M}$ ) caused a rapid, large, and transient inward current that was associated with an increase in whole-cell conductance when cells were recorded with a standard, $\mathrm{KMeSO}_{3}$-based internal solution. In contrast, as shown in Figure $1 D$, we found an initial, timedependent increase in holding current and conductance immediately after whole-cell access in cells recorded with a $\mathrm{KCl}$-based internal solution; in these cells, 3,5-DHPG caused a slower inward shift in holding current associated with a decrease in conductance. Subsequent experiments were designed to characterize the molecular basis for these two distinct agonist-sensitive currents.

\section{$\mathrm{G} \alpha_{\mathrm{q}}$-linked receptors activate TrpC3- and TrpC7-like currents in striatal cholinergic interneurons}

The transient inward current was activated by multiple $\mathrm{G} \alpha_{\mathrm{q}^{-}}$ linked receptors in striatal cholinergic interneurons. As shown in Figure $2 A$, histamine evoked a rapid inward current with kinetics and voltage dependence very similar to the 3,5-DHPG-sensitive current observed in the same cell; digital subtraction of voltage ramps before and after drug application indicated that neither agonist-induced current reversed over the voltage range tested $(-60$ to $-130 \mathrm{mV})$ (Fig. $2 \mathrm{~A}$, right). Although multiple applications of either agonist revealed marked homologous receptor desensitization (data not shown) (Berg and Bayliss, 2007), there was 
little evidence for receptor cross-desensitization; effects of 3,5-DHPG were not different when applied before or after histamine.

To examine the current-voltage $(I-V)$ relationship of these currents over a more complete range of membrane potentials, we tested agonist effects using a $\mathrm{CsMeSO}_{3}-$ based internal solution, after blocking other voltage-dependent currents (e.g., Kir, $\mathrm{CaV}$, etc.). As shown in Figure $2 B$, both histamine and 3,5-DHPG elicited a fast, transient inward current similar to that seen with the $\mathrm{KMeSO}_{3}$-based internal. The amplitude of the 3,5-DHPGevoked current was consistently smaller than histamine-induced current (ratio of $\left.I_{\mathrm{DHPG}}: I_{\text {histamine, }}, 0.60 \pm 0.14 ; n=20\right)$. The ramp $I-V$ curves for agonist-induced currents revealed a reversal potential near $-10 \mathrm{mV}$ ( $E_{\text {rev-histamine, }}-11.4 \pm 1.4 \mathrm{mV}$; $n=18 ; E_{\text {rev-DHPG }},-10.2 \pm 1.4 \mathrm{mV} ; n=$ 18) with a doubly rectifying profile, two hallmark characteristics of TrpC channels (Clapham et al., 2001).

In light of the well known activation of TrpC channels by $\mathrm{G} \alpha$-linked receptors (Clapham, 2003) and given that the $I-V$ profile of agonist-induced current in striatal interneurons is reminiscent of TrpC channels (Clapham et al., 2001), we sought pharmacological evidence for TrpC contributions to mGluR-activated currents. Because of strong homologous receptor desensitization, it was not possible to apply 3,5-DHPG before and during antagonist exposure in these experiments. Therefore, we used a protocol in which histamine was applied first, before application of the mGluR agonist in the presence of a TrpC channel blocker; this protocol enabled us to verify functional agonist-activated TrpC-like currents in each cell, and it allowed us to establish a reference against which to gauge the effect of the blockers on mGluR-evoked currents. Thus, data from these experiments are expressed as $I_{\mathrm{DHPG}}: I_{\text {histamine }}$. As expected for a mixed cationic TrpC-like current, we found a significantly reduced 3,5-DHPG response when extracellular sodium was replaced with Tris ${ }^{+}$(Fig. $\left.2 D\right)\left(I_{\mathrm{DHPG}}: I_{\text {histamine, }} 0.02 \pm 0.00 ; n=5\right)$. Likewise, consistent with the known sensitivity of TrpC channel subunits to gadolinium $\left(\mathrm{Gd}^{3+}\right)$ (Dietrich et al., 2005), we found that currents evoked by 3,5-DHPG were eliminated in the presence of $100 \mu \mathrm{M} \mathrm{Gd}^{3+}$ (Fig. 2D) ( $\left.I_{\mathrm{DHPG}}: I_{\text {histamine }}, 0.07 \pm 0.04 ; n=5\right)$.

Additional pharmacological experiments suggest a role for TrpC3 and/or TrpC7 channels, specifically, in mediating the mGluR-activated current in striatal interneurons. First, it is known that low concentrations of lanthanum $\left(\mathrm{La}^{3+}\right)$ potentiate currents carried by TrpC4 and TrpC5 (Schaefer et al., 2000; Strubing et al., 2001) but inhibit those mediated by TrpC3, TrpC6, and TrpC7 (Dietrich et al., 2005); we found that 3,5DHPG-evoked currents were essentially eliminated by $100 \mu \mathrm{M}$ $\mathrm{La}^{3+}$, consistent with involvement of TrpC3, TrpC6, or TrpC7

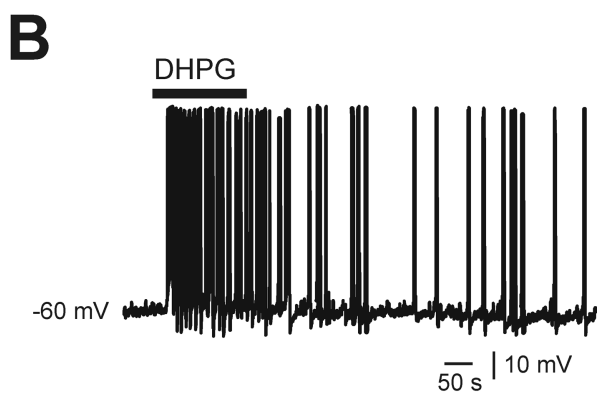

D
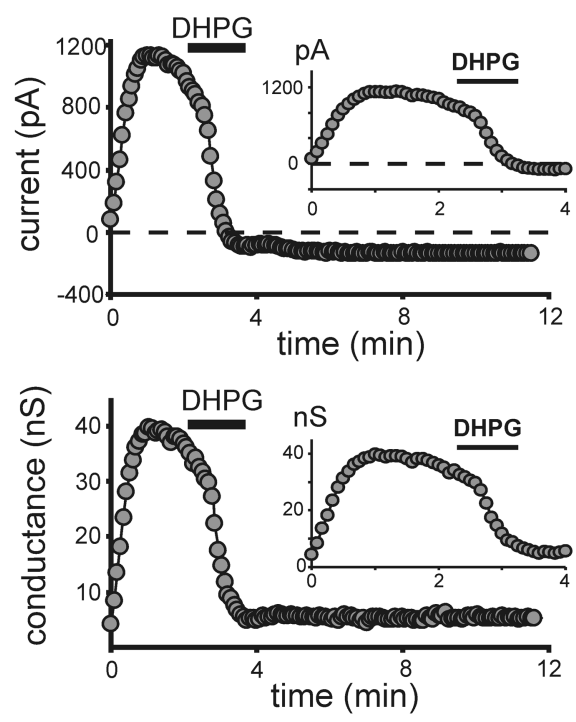

time ( $\mathrm{min})$

$\mathrm{KCl}$ internal

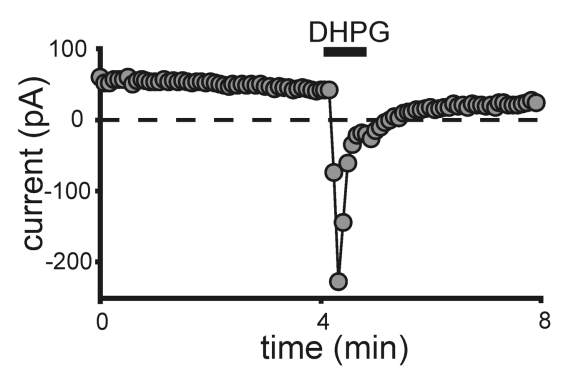

Figure 1. Two distinct ionic mechanisms can contribute to mGluR1/5 receptor-mediated increase in striatal interneuron excitability. $\boldsymbol{A}$, IR-DIC image of a large striatal interneuron directly visualized in a brain slice (arrow); smaller medium spiny cells are Iso apparent (arrowheads). Scale bar, $20 \mu \mathrm{m}$. B , Under whole-cell current clamp, 3,5-DHPG (100 $\mu \mathrm{m})$, an mGluR1/5-selective

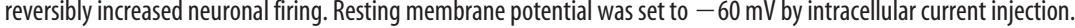
$\sim 2$ min after whole-cell access; at that point, 3,5-DHPG caused a decrease in outward holding current that was associated with a decrease in conductance. Insets, The first 4 min of the recordings are shown on an expanded time scale.

(Fig. $2 D)\left(I_{\mathrm{DHPG}}: I_{\text {histamine, }}, 0.05 \pm 0.02 ; n=5\right)$. Second, as shown for the exemplar cell of Figure $2 C$, we found that $500 \mu \mathrm{M}$ FFA blocked effects of 3,5-DHPG (Fig. $2 D)$ ( $I_{\mathrm{DHPG}}: I_{\text {histamine }}, 0.03 \pm$ $0.00 ; n=4)$. Similar to this agonist-activated current in striatal interneurons, both TrpC3 and TrpC7 are inhibited by FFA (Trebak et al., 2007); unlike the native current, however, TrpC6 currents are actually enhanced by FFA (Inoue et al., 2001). It is also noteworthy that we used $\mathrm{Cd}^{2+}(250 \mu \mathrm{M})$ to block the voltagedependent $\mathrm{Ca}^{2+}$ currents activated by depolarizing ramp voltage commands in these experiments. It is known that $\mathrm{Cd}^{2+}$ strongly inhibits TrpC6 (Inoue et al., 2001). Despite this, agonistactivated currents were clearly present in $\mathrm{Cd}^{2+}$-containing bath solution, further militating against a role for TrpC6. In sum, the $I-V$ properties and pharmacological profile of mGluR-activated currents in striatal cholinergic neurons are most similar to those mediated by TrpC3 and TrpC7 subunits.

The two group I metabotropic glutamate receptors, mGluR1 
A

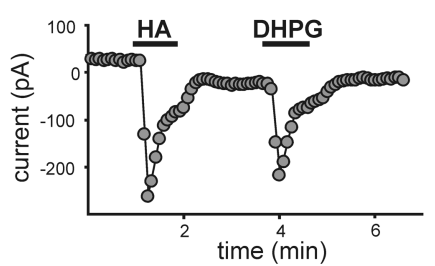

B
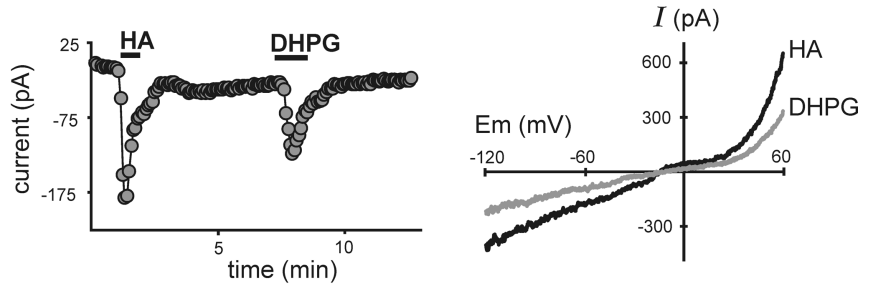

C
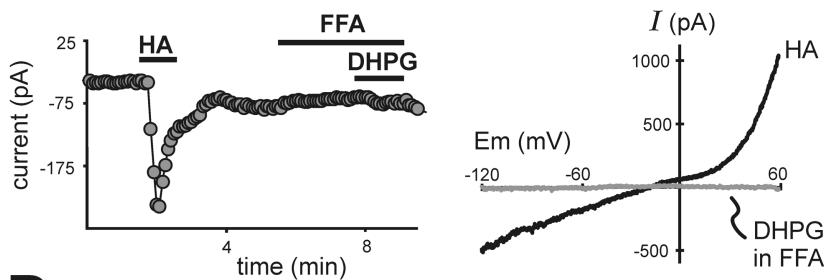

D

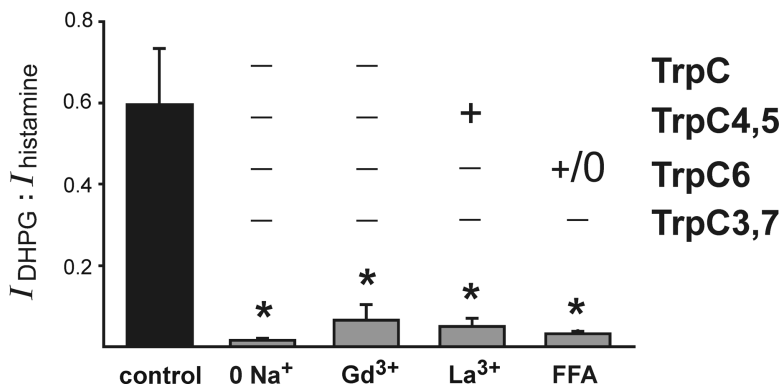

Figure 2. mGluR1/5 receptors activate TrpC-like currents in striatal cholinergic interneurons with pharmacological properties of $\operatorname{Trp} C 3$ or $\operatorname{TrpC7}$. A-C, Time series illustrating the effects of histamine (HA; $10 \mu \mathrm{M})$ and 3,5-DHPG $(50 \mu \mathrm{m})$ on holding current at $-60 \mathrm{mV}$ (left); I-V relationships of agonist-activated currents were derived by subtracting control ramp currents from those obtained in the presence of agonist (right). $\boldsymbol{A}$, In striatal interneurons recorded with a $\mathrm{KMeSO}_{3}$-based internal solution, both HA and 3,5-DHPG induced a rapid inward shift in current; the agonist-induced currents did not reverse between -60 and $-130 \mathrm{mV}$. $\boldsymbol{B}$, When recorded with a $\mathrm{CsMeSO}_{3}$-based internal solution, $\mathrm{HA}$ and 3,5-DHPG induced a rapidly desensitizing inward current; examination of agonist-sensitive currents through more depolarized potentials revealed a doubly rectifying $I-V$ profile that reversed at approximately $-10 \mathrm{mV} . \boldsymbol{C}$, In the presence of FFA (500 $\mu \mathrm{m})$, the 3,5-DHPG-activated current was essentially eliminated. D, Averaged data showing effects of different $\operatorname{TrpC}$ channel inhibitors $\left(0 \mathrm{Na}^{+}, 100 \mu \mathrm{M} \mathrm{Gd}{ }^{3+}, 100 \mu \mathrm{m}\right.$ $\mathrm{La}^{3+}$, and $500 \mu \mathrm{MFFA}$ ) on mGluR1/5 receptor-activated current; data are expressed as the amplitude ratio of 3,5-DHPG current to the histamine current measured in the same cell ( $I_{\mathrm{DHPG}}$ : $\left.I_{\text {histamine }}\right)$. The combined pharmacological profile is consistent with $\operatorname{TrpC} 3$ and $\operatorname{TrpC} 7$ channels. ${ }^{*} p<0.0001$ by ANOVA.

and mGluR5, are expressed in striatal cholinergic neurons (Tallaksen-Greene et al., 1998; Conn et al., 2005), and 3,5-DHPG is an agonist at both receptors. We found that preincubation with MPEP (15-20 min; $25 \mu \mathrm{M}$ ), an mGluR5-specific antagonist (Micheli, 2000), only partially reduced 3,5-DHPG-activated currents $\left(I_{\text {DHPG }}: I_{\text {histamine, }}, 0.22 \pm 0.06 ; n=9\right)$, whereas CPCCOEt (15-30 min; $100 \mu \mathrm{M}$ ), a purported mGluR1 antagonist with sig- nificant activity at mGluR5 receptors (Annoura et al., 1996), completely blocked the 3,5-DHPG-activated current in five of six cells $\left(I_{\mathrm{DHPG}}: I_{\text {histamine }}, 0.01 \pm 0.00 ; n=5\right)$ and caused a partial reduction in one cell $\left(I_{\mathrm{DHPG}}: I_{\text {histamine }}, 0.15\right)$. Thus, it appears that both mGluR1 and mGluR5 contribute to activation of TrpC-like currents in striatal cholinergic interneurons.

\section{TrpC 3 and $\operatorname{TrpC} 7$ are expressed in striatal} cholinergic interneurons

Based on the pharmacological profile of the agonist-evoked transient inward currents, we performed in situ hybridization to examine striatal expression of the closely related TrpC3, TrpC6, and TrpC7 subunits (Fig. 3). Horizontal brain sections from P10-P18 rats $(n=4)$ were hybridized with antisense and sense $\left[{ }^{33} \mathrm{P}\right]$ labeled cRNA probes; labeling with sense strand probes was uniformly low (data not shown). As evident in the film autoradiographs (Fig. $3 A$ ), TrpC3 probes gave the strongest signal in the striatum, but both TrpC3 and TrpC7 were expressed in a punctate distribution pattern reminiscent of striatal cholinergic interneurons. For TrpC7, in addition to the punctate labeling, we also noticed a mediolateral gradient of expression that may reflect relatively stronger expression of TrpC7 in medially located GABAergic output neurons. Consistent with previous reports, TrpC6 expression was undetectable in the striatum, with labeling in the brain primarily localized to the dentate gyrus of the hippocampus (Otsuka et al., 1998). The scattered distribution of intensely labeled large striatal neurons is presented in dark-field images from emulsion-dipped slides for sections hybridized with TrpC3 and TrpC7 probes (Fig. 3B, left), and high-power brightfield images reveal dense accumulations of silver grains overlying large neurons labeled for both TrpC3 and TrpC7, with particularly strong expression apparent for TrpC3 (Fig. 3B, right). To verify that the distributed large TrpC3- and TrpC7-expressing neurons were indeed cholinergic, we combined nonisotopic in situ hybridization for TrpC3 and TrpC7 with immunohistochemistry for ChAT, a marker of cholinergic neurons (Fig. 3C). Consistent with expression of these TrpC channels in cholinergic interneurons, we found extensive colocalization of ChAT immunoreactivity with TrpC3 and TrpC7 mRNA in coronal sections through the striatum.

\section{mGluR 1 and mGluR5 activate TrpC3 and TrpC7 in a heterologous expression system}

TrpC channels are renowned for their activation by $\mathrm{G} \alpha_{\mathrm{q}}$-linked receptors, such as group I mGluRs and $\mathrm{H} 1$ histamine receptors. However, a previous report suggested that mGluR1 selectively activates TrpC1 channels in CHO cells, consistent with a selective physical association demonstrated between mGluR1 and TrpC1; mGluR1 did not bind other TrpC subunits, including TrpC2TrpC6 (TrpC7 was not tested) and, of relevance here, did not activate TrpC3 channels (Kim et al., 2003). In addition, mGluR5 reportedly did not interact with any of the tested TrpC channel subunits, including TrpC3 (Kim et al., 2003). However, our pharmacological and neuroanatomical data suggest a contribution from TrpC3 and TrpC7 to cationic currents activated by mGluR1/5 and histamine receptors in striatal cholinergic interneurons. In light of this, we cotransfected mGluR1 or mGluR5 with TrpC3 or TrpC7 in mammalian cells to test whether both group I mGluRs are able to activate the particular TrpC channel subunits expressed in striatal cholinergic interneurons. Indeed, as shown in Figure 4, we found that all combinations of mGluR and TrpC channel were functionally compatible in HEK293T cells; 3,5-DHPG activated TrpC3 and TrpC7 via either mGluR1 
or mGluR5 ( $n \geq 5$ for each combination of receptor and channel). In addition, in HEK293T cells cotransfected with the H1 histamine receptor, we found that histamine activated both TrpC3 and TrpC7 ( $n=5$ and $n=2$, respectively; data not shown). Thus, we find no evidence for selectivity in activation of TrpC3 and TrpC7 by either mGluR1 or mGluR5, at least in HEK293T cells, and we verify that group I mGluRs and $\mathrm{H} 1$ receptors are capable of activating the TrpC channels expressed in cholinergic interneurons.

\section{Group I mGluRs inhibit a chloride- activated $\mathrm{K}^{+}$channel in striatal cholinergic interneurons}

As mentioned earlier, in recordings from striatal interneurons using $\mathrm{a} \mathrm{Cl}^{-}$-based internal solution, we found a rapid increase in outward holding current that was associated with an increase in conductance (Figs. $1 D, 5 A$, inset). In the absence of further manipulation, the current showed variable degrees of run down $(37 \pm 6 \%$ decrease in current at $120 \mathrm{~s}$ after the peak; $n=8$ ). To characterize this apparently $\mathrm{Cl}^{-}$-sensitive current, we used digital subtractions of ramp $I-V$ curves taken from the beginning of a recording, before significant run up, and from a point near the peak of the run-up current. Difference currents revealed that run up was caused by activation of an outwardly rectifying $\mathrm{K}^{+}$current (Fig. 5A). By comparison to that recorded with the $\mathrm{KMeSO}_{3}$-based internal solution, outward holding current was $\sim 10$-fold greater with a KCl-based pipette solution that was otherwise identical in composition $\left(\mathrm{KMeSO}_{3}, 73.2 \pm 19.6 \mathrm{pA}\right.$; $n=6 ; \mathrm{KCl}, 669.3 \pm 61.9 \mathrm{pA} ; n=29 ; p<0.001)$. The run-up current did not appear to require intracellular $\mathrm{Na}^{+}$, which was present at only low levels in the $\mathrm{KCl}$-based internal solution $(<1 \mathrm{~mm})$.

Importantly, this $\mathrm{Cl}^{-}$-sensitive $\mathrm{K}^{+}$run-up current was nearly completely inhibited by mGluR activation, as illustrated in Figure $5 B$ (see also Fig. $1 D$ ); under these recording conditions, 3,5DHPG inhibited an outwardly rectifying $\mathrm{K}^{+}$current, with $I-V$ properties similar to the run-up current but distinctly different from the 3,5-DHPG-activated current observed with our $\mathrm{MeSO}_{3}$-based internal solutions. We also found that the run-up current was strongly inhibited by isoflurane (Fig. 5C), distinguishing this outwardly rectifying $\mathrm{K}^{+}$current from the TASK-3like leak $\mathrm{K}^{+}$current that we have identified previously in these cells, which is substantially smaller and activated by inhalational anesthetics (Berg and Bayliss, 2007).

We used gramicidin perforated-patch recordings from striatal interneurons to determine whether receptor-modulated $\mathrm{K}^{+}$currents were evident at unperturbed ambient levels of intracellular chloride. In the majority of striatal interneurons recorded with gramicidin ( $n=9$ of 13$)$, mGluR1/5 or histamine H1 receptor activation resulted in a transient inward current associated with an increase in conductance (data not shown), essentially identical to the agonist-activated TrpC-like currents obtained in whole- cell recordings with the $\mathrm{KMeSO}_{3}$-based internal solution (Fig. $1 C)$. However, in a subset of cells ( $n=4$ of 13 cells), we found that the 3,5-DHPG-evoked current was associated with a decrease in conductance (Fig. 6A); in three of those cells, the agonist induced a biphasic effect on conductance, with a transient increase followed by a later decrease in conductance. This biphasic effect on conductance likely represents rapid activation and desensitization of the TrpC-like mixed cationic current followed by slower inhibition of a $\mathrm{K}^{+}$current (Fig. $6 B$, early and late $I-V$ curves). In further support of this possibility, after application of lanthanum to inhibit TrpC-like currents in two of these cells, we found that 3,5-DHPG and histamine evoked only the slower decrease in conductance (Fig. $6 \mathrm{~A}$ ), and $I-V$ curves before and during agonist exposure in $\mathrm{La}^{3+}$ revealed that the decrease in conductance was caused by inhibition of a weakly outwardly rectifying $\mathrm{K}^{+}$current (Fig. 6C). Thus, the TrpC-like current appeared to provide the predominant agonist-sensitive current under relatively unperturbed recording conditions, although a $\mathrm{K}^{+}$current contribution was also occasionally encountered.

\section{Slo2.1 (Slick), a Cl- ${ }^{-}$activated $\mathrm{K}^{+}$channel subunit, is} prominently expressed in striatal cholinergic interneurons Our recordings indicate the presence of $\mathrm{a} \mathrm{Cl}^{-}$-activated $\mathrm{K}^{+}$current in striatal interneurons, suggesting a possible contribution from a member of the Slo2 subfamily of $\mathrm{Na}^{+}$- and $\mathrm{Cl}^{-}$-activated $\mathrm{K}^{+}$channels. These relatively recently identified $\mathrm{K}^{+}$channel subunits include Slo2.1 (Slick) and Slo2.2 (Slack), which share 

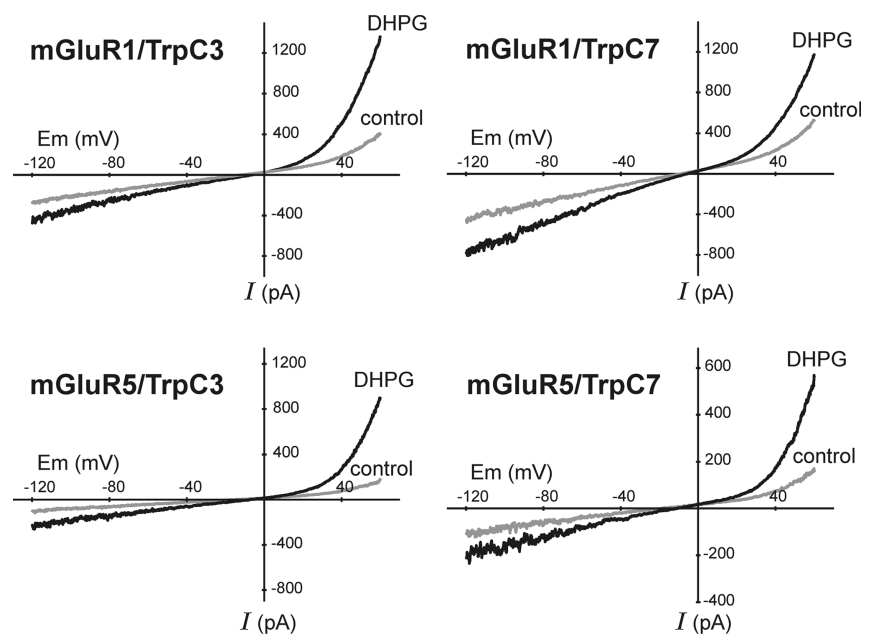

Figure 4. $\operatorname{TrpC} 3$ and $\operatorname{Trp} C 7$ are activated by both group I mGluRs, mGluR1 and mGluR5. HEK293T cells were cotransfected with either TrpC 3 or TrpC7 and mGluR1 or mGluR5. Cells were held at $-60 \mathrm{mV}$, and depolarizing ramps $(\Delta 0.13 \mathrm{mV} / \mathrm{ms})$ were applied at $5 \mathrm{~s}$ intervals under control conditions and during exposure to the mGluR1/5 agonist, 3,5-DHPG (50 $\mu \mathrm{M})$. Ramp $/-V$ curves are presented from the control period and during exposure to the receptor agonist, as indicated, for all combinations of channel and receptor. In all cases, activation of mGluR1 or mGluR5 activated either TrpC3 and TrpC7, as evidenced by the 3,5-DHPG-induced increase in inward and outward current ( $n \geq 5$ for each combination of receptor and channel).

substantial sequence homology but differ in $\mathrm{Na}^{+}$and $\mathrm{Cl}^{-}$sensitivity (Bhattacharjee and Kaczmarek, 2005); whereas Slo2.2 has an absolute requirement for intracellular $\mathrm{Na}^{+}$, Slo2.1 displays $\mathrm{Cl}^{-}$-dependent activity even in the absence of $\mathrm{Na}^{+}$.

We performed in situ hybridization to examine expression of Slo2.1 and Slo2.2 in the striatum. As shown in Figure 7, both Slo2 transcripts are present, but they appear in strikingly different patterns. Low-power autoradiographs revealed a sparse distribution of Slo2.1-expressing neurons in striatum that resembles the known pattern of cholinergic interneurons (Fig. 7A); in contrast, Slo2.2 expression was comparatively higher and uniformly dense throughout the striatum (Fig. 7E). Higher-power photomicrographs of emulsion-dipped slides showed a punctate expression pattern for Slo2.1, with high levels of silver grains overlying large cells (Fig. 7C,D). Expression of Slo2.2 appeared to be confined to smaller, presumably medium spiny neurons (Fig. 7G,H), but examination of high-power emulsion autoradiographs revealed a subpopulation of those smaller striatal cells that was apparently devoid of labeling (Fig. 7H). By combining nonisotopic in situ hybridization for Slo2.1 and Slo2.2 with ChAT immunohistochemistry, we confirmed expression of the $\mathrm{Cl}^{-}$-sensitive Slo2.1 channel in striatal cholinergic interneurons (Fig. $8 \mathrm{~A}$ ), whereas we found no evidence for expression of Slo2.2 in ChATimmunoreactive striatal neurons (Fig. 8C).

Slo2.1, like the native interneuron $\mathrm{Cl}^{-}$-activated $\mathrm{K}^{+}$current, is inhibited by inhalational anesthetics and mGluR receptor activation

To determine whether Slo2.1 channels have pharmacological and kinetic properties similar to those of the native $\mathrm{Cl}^{-}$-activated, DHPG-sensitive $\mathrm{K}^{+}$current in striatal cholinergic interneurons, we expressed a GFP-tagged Slo2.1 channel construct in HEK293T cells (Fig. 9). In recordings from transfected cells with a $\mathrm{Cl}^{-}$based internal solution, we found an outwardly rectifying $\mathrm{K}^{+}$ channel with properties like those described previously for Slo2.1 (Bhattacharjee et al., 2003). Consistent with the anesthetic sensi-


Figure 5. Chloride activates an outwardly rectifying $\mathrm{K}^{+}$current in striatal interneurons that is inhibited by $\mathrm{mGluR} 1 / 5$ receptors and inhalational anesthetics. Neurons were held at -60 $\mathrm{mV}$, and hyperpolarizing ramps $(\Delta-0.05 \mathrm{mV} / \mathrm{ms})$ were applied every $5 \mathrm{~s}$ while recording with a $\mathrm{Cl}^{-}$-based internal solution. $\boldsymbol{A}$, Subtraction of ramp $I-V$ curves taken immediately after whole-cell access and $100-200$ s later shows activation of an outwardly rectifying $\mathrm{K}^{+}$current. Inset, Time course of the increase in holding current (at $-60 \mathrm{mV}$ ). $B, C$, Modulation of the chloride-activated $\mathrm{K}^{+}$current. Subtracted ramp $I-V$ curves illustrate an outwardly rectifying $\mathrm{K}^{+}$current inhibited by $50 \mu \mathrm{m} 3,5-\mathrm{DHPG}(\boldsymbol{B})$ and by $1.9 \%$ isoflurane $(\boldsymbol{C})$ in cells recorded with $\mathrm{KCl}$-based internal solutions. Insets, Time courses depicting the initial increase in holding current and the subsequent inhibition of that run-up current by 3,5-DHPG or isoflurane.

tivity we observed for the native $\mathrm{Cl}^{-}$-sensitive $\mathrm{K}^{+}$current in cholinergic interneurons, we found that Slo2.1 channel currents were also strongly inhibited by isoflurane (Fig. $9 A)(78.4 \pm 1.6 \%$ inhibition; $n=8$ ). Likewise, cloned Slo2.1 channel currents were inhibited by activation of coexpressed group I mGluRs (mGluR1, $60.2 \pm 7.1 \%$ inhibition; $n=7$; mGluR5, $75.7 \pm 3.8 \%$ inhibition; $n=7$ ) in HEK293T cells (Fig. 9B), recapitulating the mGluR modulation of $\mathrm{Cl}^{-}$-activated $\mathrm{K}^{+}$currents in striatal cholinergic interneurons. In addition, voltage step commands revealed that the native $\mathrm{Cl}^{-}$-activated, DHPG-sensitive interneuron $\mathrm{K}^{+}$current displays essentially instantaneous activation kinetics, like 
Slo2.1 channel currents (supplemental Fig. 1, available at www.jneurosci.org as supplemental material) (see also Bhattacharjee et al., 2003).

In light of the 3,5-DHPG-evoked inhibition of interneuron current that we observed, one might also argue to exclude a Slo2. 2 contribution to the native agonistsensitive $\mathrm{K}^{+}$current based on the differential receptor modulation described previously for Slo2 subunits (Santi et al., 2006); when coexpressed in Xenopus oocytes, $\mathrm{G} \alpha$-linked receptors reportedly inhibited Slo2.1 but activated Slo2.2 (Santi et al., 2006). However, we found that both Slo2 channels are inhibited by $\mathrm{G} \alpha$-linked receptors in a mammalian expression system (e.g., TRHR1 in HEK293 cells) (see supplemental Fig. 2, available at www.jneurosci.org as supplemental material), indicating that differential receptor modulation cannot be used to distinguish between Slo2.1 and Slo2.2. It is also noteworthy that whereas Slo2.1 channels are apparently inhibited by intracellular ATP, as clearly demonstrated in excised patches (Bhattacharjee et al., 2003), we found no inhibition of whole-cell $\mathrm{Cl}^{-}$-activated $\mathrm{K}^{+}$currents by intracellular ATP (3 mM) in striatal interneurons $[454.6 \pm 97.4$ vs $655.5 \pm 60.9 \mathrm{pA}$ in the absence and presence of ATP; $n=7$ and 26; not significant (NS) by unpaired $t$ test] or in Slo2.1-expressing HEK293T cells $(175.2 \pm 72.5$ vs $220.9 \pm 56.0 \mathrm{pA} / \mathrm{pF}$ in the absence and presence of ATP; $n=6$ and 7 ; NS).

\section{Discussion}

Striatal cholinergic interneurons receive a major excitatory glutamatergic input that causes membrane depolarization and increased ACh release via activation of $\mathrm{G} \alpha_{\mathrm{q}^{-}}$ linked metabotropic glutamate receptors (mGluR1/5) (Takeshita et al., 1996; Marti et al., 2001; Bell et al., 2002). Our experiments implicate members of two different ion channel families (TrpC3 and/or TrpC7 mixed-cationic channels and Slo2.1 NaClsensitive $\mathrm{K}^{+}$channels) as molecular substrates for this mGluR1/5 signaling. All three of these channel subunits are expressed in striatal cholinergic interneurons, as determined by combined immunohistochemistry and in situ hybridization, but the relative contribution of TrpC and Slo2.1 channels to mGluR1/5sensitive current is dependent on intracellular chloride concentration. When $\left[\mathrm{Cl}^{-}\right]_{\mathrm{i}}$ was maintained at low levels, 3,5-DHPG activated a transient mixed-cationic current with voltage dependence and pharmacological profile of TrpC3 and TrpC7. When interneurons were recorded with a $\mathrm{Cl}^{-}$-based internal solution, inhibition of an anesthetic-sensitive
A
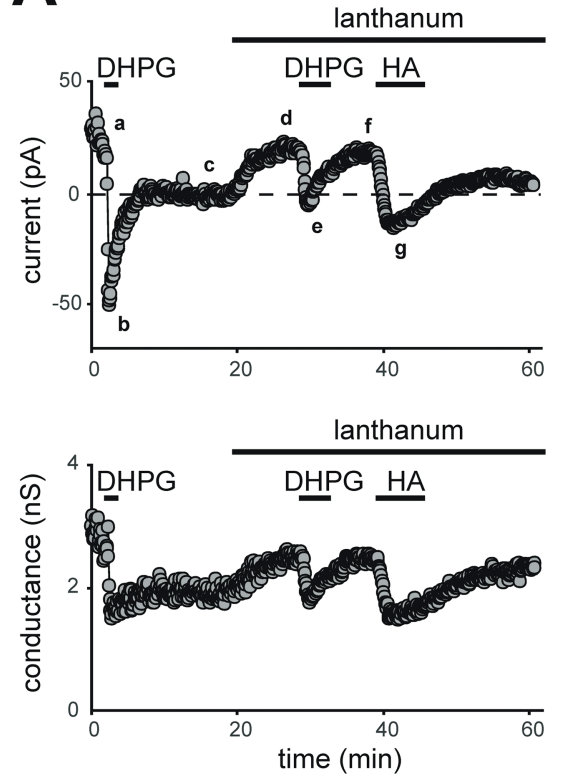

B DHPG-sensitive current

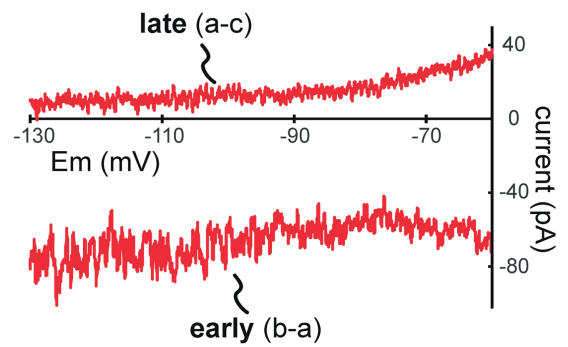

agonist-sensitive current in lanthanum

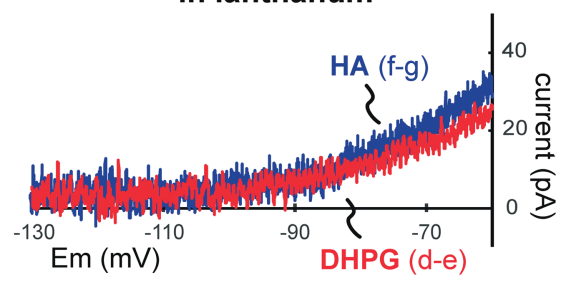

Figure 6. Receptor-sensitive cationic and potassium currents in striatal interneuron recorded with gramicidin. $A$, Representative time series of an interneuron recorded using gramicidin perforated patch; the cell was held at $-60 \mathrm{mV}$, and hyperpolarizing $\operatorname{ramps}(\Delta-0.05 \mathrm{mV} / \mathrm{ms})$ were applied every 5 s while agonists were applied under control conditions and in the presence of $\mathrm{La}^{3+}$ $(100 \mu \mathrm{M})$. Effects of 3,5-DHPG $(50 \mu \mathrm{M})$ and histamine (HA; $10 \mu \mathrm{M}$ ) on holding current (top) and slope conductance (bottom; from $-60 \mathrm{mV}$ to $-80 \mathrm{mV}$ ) are illustrated. $\boldsymbol{B}, I-V$ relationships of 3,5-DHPG-sensitive currents derived from two time points (early and late) under control conditions illustrate a biphasic change in conductance occasionally encountered in these recordings. The early $I-V$ curve reflects activation by $3,5-\mathrm{DHPG}$ of a current that does not reverse between -60 and $-130 \mathrm{mV}$, whereas the late $I-V$ curve is consistent with inhibition by 3,5-DHPG of an outwardly rectifying current. C, Subtracted ramp I-V curves of currents evoked by 3,5-DHPG (red) and histamine (blue) in the presence of $\mathrm{La}^{3+}$ reflect only inhibition of the outwardly rectifying $\mathrm{K}^{+}$current.
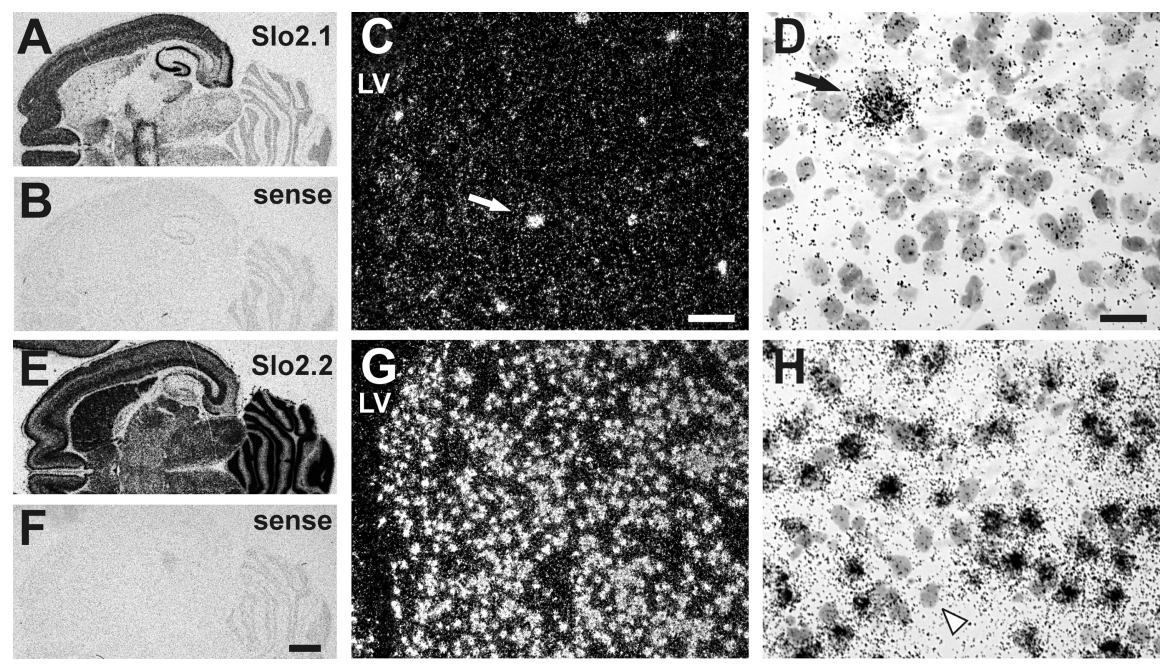

Figure 7. Differential expression of Sl02.1 (Slick) and Slo2.2 (Slack) in rat striatum. Slo2.1 and Slo2.2 mRNA were detected in horizontal sections through the rat brain by in situ hybridization using $\left[{ }^{33} \mathrm{P}\right]$-labeled cRNA probes. $\boldsymbol{A}, \boldsymbol{B}, \boldsymbol{E}, \boldsymbol{F}$, Film autoradiographs showed differential expression of Slo2.1 (A) and Slo2.2 (E) in the CNS, with substantially more widespread expression of Slo2.2 mRNA; we observed no labeling with sense control probes $(\boldsymbol{B}, \boldsymbol{F}) . \boldsymbol{C}, \boldsymbol{D}, \boldsymbol{G}, \boldsymbol{H}$, Photomicrographs from emulsion-dipped slides under dark-field $(\boldsymbol{C}, \boldsymbol{G})$ and bright-field $(\boldsymbol{D}, \boldsymbol{H})$ illumination present expression patterns of Slo2.1 $(\boldsymbol{C}, \boldsymbol{D})$ and Slo2.2 $(\boldsymbol{G}, \boldsymbol{H})$ within the striatum. A distributed population of large striatal cells expressed Slo2.1. The arrow in $\boldsymbol{C}$ indicates the cell shown at higher magnification in $\boldsymbol{D}$. $\mathbf{G}, \boldsymbol{H}$, Slo2.2 mRNA was more widely localized throughout the striatum $(\boldsymbol{G})$, as expected for expression in medium spiny neurons; note, however, the presence of a small subpopulation of unlabeled medium-sized cells (see $\boldsymbol{H}$, arrowhead). LV, Lateral ventricle. Scale bars: $\boldsymbol{A}, \boldsymbol{B}, \boldsymbol{E}, \boldsymbol{F}, 2 \mathrm{~mm} ; \boldsymbol{C}, \boldsymbol{G}, 100 \mu \mathrm{m} ; \boldsymbol{D}, \boldsymbol{H}, 25 \mu \mathrm{m}$.

$\mathrm{Cl}^{-}$-activated $\mathrm{K}^{+}$current accounted entirely for the effects of mGluR1/5 receptor stimulation. In HEK293T cells, heterologous coexpression of Slo2.1 with either mGluR1 or mGluR5 recapitulated salient properties of the native interneuron $\mathrm{Cl}^{-}$-activated 


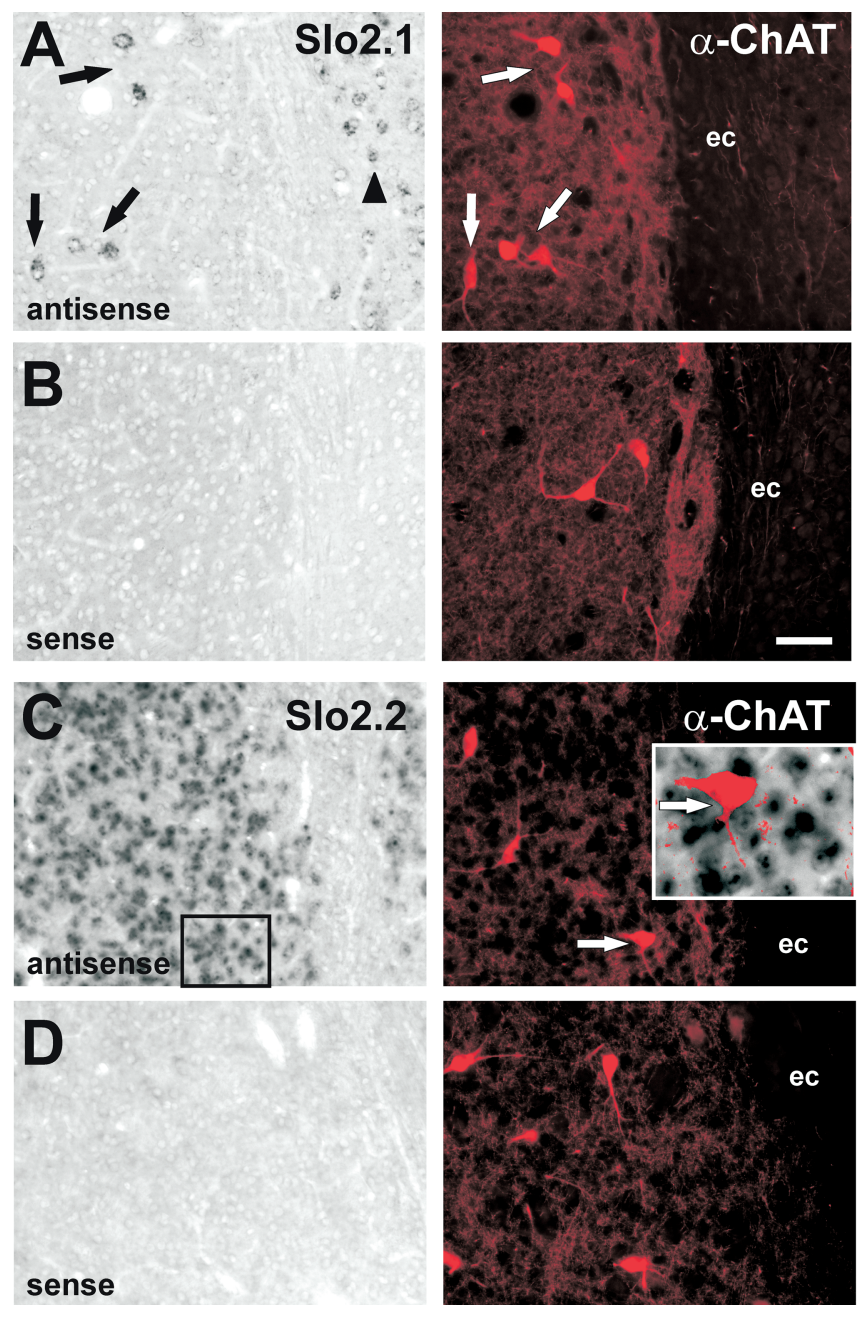

Figure 8. Slo2.1 (Slick) is expressed in striatal cholinergic interneurons. $\boldsymbol{A}-\boldsymbol{D}$, Nonisotopic in situ hybridization using digoxigenin-labeled antisense $(\boldsymbol{A}, \boldsymbol{C})$ and sense $(\boldsymbol{B}, \boldsymbol{D})$ cRNA probes (left) for Slo2.1 $(\boldsymbol{A}, \boldsymbol{B})$ and Slo2.2 ( $\boldsymbol{C}, \boldsymbol{D})$ was combined with immunohistochemistry for $C$ ChAT (right) in coronal sections of rat striatum. ChAT-immunopositive striatal cholinergic interneurons labeled with the Slo2.1 probe are indicated (arrows); noncholinergic cortical neurons expressing Slo2.1 are also identified ( $\boldsymbol{A}$, arrowhead). Slo2.2 labeling was not observed in ChAT-immunoreactive striatal interneurons ( $\boldsymbol{C}$; expanded view of the boxed area is provided as an inset). No labeling for Slo2.1 or Slo2.2 was obtained with either of the sense strand control probes. ec, External capsule. Scale bar, $50 \mu \mathrm{m}$.

$\mathrm{K}^{+}$current, notably inhibition by isoflurane and 3,5-DHPG. When $\left[\mathrm{Cl}^{-}\right]_{\mathrm{i}}$ was relatively unperturbed in gramicidin perforated-patch recordings, the TrpC-like current was predominant. In sum, our data suggest that $\operatorname{TrpC} 3 / \operatorname{TrpC} 7$ activation accounts primarily for mGluR-mediated excitation of cholinergic interneurons at ambient $\left[\mathrm{Cl}^{-}\right]_{\mathrm{i}}$. Our studies also identify a native neuronal correlate for Slo2.1; this $\mathrm{NaCl}$-activated $\mathrm{K}^{+}$channel may contribute to background and mGluR-sensitive currents in striatal interneurons when intracellular $\left[\mathrm{Cl}^{-}\right]$or $\left[\mathrm{Na}^{+}\right]$are elevated.

Ionic mechanisms underlying mGluR activation of cholinergic interneurons

Our data indicate that $\mathrm{G} \alpha_{\mathrm{q}}$-linked mGluR1/5 and histamine receptors primarily activate a large TrpC-like current in striatal cholinergic interneurons, with contribution from a smaller background $\mathrm{K}^{+}$current observed in a subset of cells. In a number of previous studies, however, inhibition of a background $\mathrm{K}^{+}$current was implicated in the modulation of striatal interneurons by $\mathrm{G} \alpha$-linked receptors (Takeshita et al., 1996; Calabresi et al., 1999; Bell et al., 2000). Our finding that the predominant receptor-mediated ionic current is influenced by $\left[\mathrm{Cl}^{-}\right]_{\mathrm{i}}$ provides some resolution for these apparently conflicting results. Initial reports that described mGluR1/5- and histamine H1-mediated inhibition of a $\mathrm{K}^{+}$current in striatal interneurons used nystatin perforated-patch recordings, in which the pipette solution contained $150 \mathrm{~mm} \mathrm{KCl} \mathrm{(Munakata} \mathrm{and} \mathrm{Akaike,} \mathrm{1994;} \mathrm{Takeshita} \mathrm{et} \mathrm{al.,}$ 1996). Because nystatin channels are permeable to chloride (Kyrozis and Reichling, 1995), interneuron $\left[\mathrm{Cl}^{-}\right]_{\mathrm{i}}$ would have increased over time toward the higher $\left[\mathrm{Cl}^{-}\right]$of the pipette. Similarly, Calabresi et al. (1999) used intracellular recordings with $2 \mathrm{M}$ KCl-filled electrodes to show that 3,5-DHPG inhibits a background $\mathrm{K}^{+}$current in striatal interneurons. Our results suggest that the high $\left[\mathrm{Cl}^{-}\right]_{\mathrm{i}}$ obtained in those previous recordings would increase Slo2.1 activity in striatal interneurons, providing a $\mathrm{K}^{+}$ channel effector for $\mathrm{G} \alpha_{\mathrm{q}}$-linked receptor signaling, while also inhibiting receptor-mediated $\mathrm{TrpC}$ channel activation. In agreement with this interpretation, agonist effects in striatal interneurons observed with lower pipette $\left[\mathrm{Cl}^{-}\right]$(nominally $14 \mathrm{~mm}$ ) appeared to include contributions from both activation of a cationic current and inhibition of a $\mathrm{K}^{+}$-selective current (Bell et al., 2000, 2002). The more extreme differences in the $\left[\mathrm{Cl}^{-}\right]_{\mathrm{i}}$ that we used ( $\leq 7$ vs $145 \mathrm{~mm}$ ) revealed the constituent TrpC- and Slo2.1-like currents in relative isolation.

TrpC3 and TrpC7 are major receptor-activated ion channel targets in the striatum

We found that two $\mathrm{G} \alpha_{\mathrm{q}}$-linked receptor agonists, 3,5-DHPG and histamine, activated a TrpC-like mixed cationic current in striatal cholinergic interneurons. It is well known that canonical TrpC channels are activated by $\mathrm{G} \alpha$-linked receptors in heterologous expression systems (Clapham, 2003). However, molecular identification of native agonist-activated TrpC channels is hindered by a lack of subunit-selective reagents and by the possibility that native currents may include distinct contributions from an admixture of homomeric and heteromeric TrpC channels. Nevertheless, we were able to tentatively attribute the native receptoractivated current in striatal cholinergic interneurons to TrpC3 and TrpC7 based on shared voltage-dependent and pharmacological properties and by exclusion of other TrpC family members.

In short, a role for TrpC2 is unlikely because it was expressed only in the vomeronasal organ (Liman et al., 1999). Homomeric TrpC1 channels generate inwardly rectifying currents, and heteromeric TrpC1:TrpC4 and TrpC1:TrpC5 channels generate outwardly rectifying currents (Clapham et al., 2001), unlike the doubly rectifying receptor-activated current in striatal interneurons. A contribution from $\mathrm{TrpC} 4$ and $\mathrm{TrpC} 5$ is also unlikely because those subunits are activated by micromolar concentrations of lanthanum (Schaefer et al., 2000), whereas we found that $\mathrm{La}^{3+}$ inhibited the receptor-sensitive current in striatal interneurons. We could also exclude TrpC6 from the remaining subgroup of candidate TrpC channels. TrpC6 is inhibited by $\mathrm{Cd}^{2+}$ and activated by FFA (Inoue et al., 2001), whereas the receptorsensitive current in striatal interneurons was retained in the presence of $\mathrm{Cd}^{2+}$ and inhibited by FFA. However, the doubly rectifying $I-V$ curve and pharmacology of the native current closely matched those of TrpC3 and TrpC7 channel currents. Corroborating these results, we found that TrpC6 transcripts were undetectable in the striatum, whereas both TrpC3 and TrpC7 were 
expressed in striatal cholinergic interneurons. The development of tools to selectively target TrpC3 and TrpC7 subunits will be necessary to verify the contribution of these two subunits to agonist-activated cationic currents in cholinergic interneurons.

It is known that both group I mGluRs, mGluR1 and mGluR5, are coexpressed in the majority of striatal cholinergic interneurons (Tallaksen-Greene et al., 1998). Accordingly, we found that both receptors couple to native TrpC-like currents in those cells and to TrpC3 and TrpC7 in a heterologous expression system. Previous pharmacological experiments also demonstrated that 3,5-DHPG-stimulated interneuron depolarization and striatal ACh release were fully blocked only by using antagonists to both mGluR1 and mGluR5 (Marti et al., 2001; Pisani et al., 2001). Likewise, both mGluR1 and mGluR5 contribute to 3,5-DHPG-induced inward current in septohippocampal cholinergic neurons (Wu et al., 2004) and to a TrpClike current in CA3 pyramidal cells (Gee et al., 2003). In contrast, distinct effects of these receptors have been reported in other cell types. In CA1 pyramidal neurons, for example, mGluR1 activation enhances $\mathrm{Na}^{+}$-dependent inward current, whereas mGluR5 activation suppresses spike afterhyperpolarization (Mannaioni et al., 2001). In cerebellar Purkinje neurons, TrpC1 interacts with mGluR1 and not with mGluR5, and a current ascribed to TrpC1 was selectively activated only by mGluR1 (Kim et al., 2003). The mediator(s) downstream of both mGluR1 and mGluR5 that activate striatal interneuron TrpC-like currents remain to be determined. In this respect, mGluR1/5 receptor agonists activate phospholipase C (PLC) in the striatum (Pintor et al., 2000), and both TrpC3 and TrpC7 can be activated by DAG (Clapham, 2003), a product of PLC-mediated $\mathrm{PIP}_{2}$ hydrolysis. Interestingly, because mGluR activation of TrpC-like currents in interneurons was totally absent in recordings obtained with $\mathrm{Cl}^{-}$-based internal solution, our results suggest that this signaling pathway is sensitive to raised $\left[\mathrm{Cl}^{-}\right]_{\mathrm{i}}$. In this respect, we found that recombinant $\operatorname{TrpC} 3$ and TrpC7 could be activated by mGluRs in HEK293T cells recorded with the same $\mathrm{Cl}^{-}$-based internal solution that was incompatible with $\operatorname{TrpC}$ channel activation in the interneurons, suggesting that this cannot be caused by a direct $\mathrm{Cl}^{-}$sensitivity of the TrpC channels (see supplemental Fig. 3, available at www.jneurosci.org as supplemental material).

\section{Expression and modulation of Slo2.1 in striatal cholinergic interneurons}

With a $\mathrm{Cl}^{-}$-based internal solution, we found an $\sim 10$-fold increase in outward holding current near resting membrane potential in striatal cholinergic interneurons that could be attributed to $\mathrm{Cl}^{-}$-dependent activation of an outwardly rectifying $\mathrm{K}^{+}$current, as expected for recently identified $\mathrm{NaCl}$-sensitive $\mathrm{Slo} 2$ channel subunits. Fortuitously, our pipette solution contained very low levels of $\mathrm{Na}^{+}$(nominally $<1 \mathrm{mM}$ ), ruling out the Slo2.2 subunits
rSlo2.1

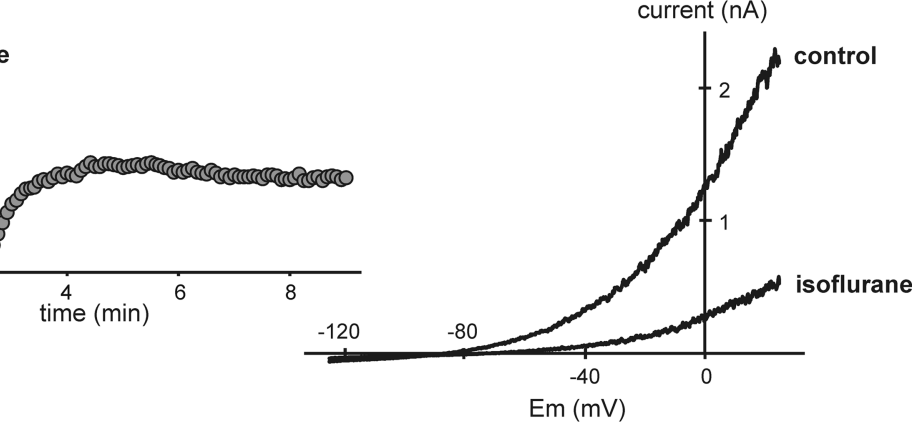

rrent $(n A)$

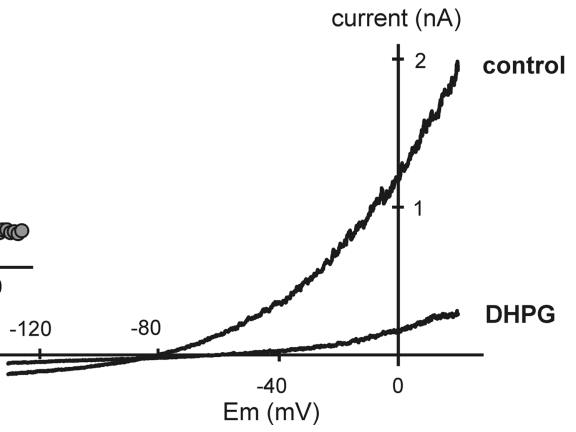

$\mathrm{Em}(\mathrm{mV})$ that have an absolute requirement for $\mathrm{Na}^{+}$(Bhattacharjee and Kaczmarek, 2005). In contrast, similar to the $\mathrm{Cl}^{-}$-activated $\mathrm{K}^{+}$ current in striatal interneurons, heterologously expressed Slo2.1 shows substantial $\mathrm{Cl}^{-}$-stimulated activity even in the absence of $\mathrm{Na}^{+}$(Bhattacharjee et al., 2003). Moreover, we found that both the native interneuron current and Slo2.1 channels are inhibited by inhalational anesthetics and mGluR receptor stimulation. In further support of the conclusion that Slo2.1 accounts for the native $\mathrm{Cl}^{-}$-activated $\mathrm{K}^{+}$current, Slo2.1 was expressed in striatal cholinergic interneurons, whereas Slo2.2 appeared to be exclusively, although not universally, expressed in medium spiny neurons.

We found little evidence for a prominent $\mathrm{Cl}^{-}$-activated $\mathrm{K}^{+}$ current at basal levels of $\left[\mathrm{Cl}^{-}\right]_{\mathrm{i}}$ obtained with gramicidin perforated-patch recordings from cholinergic interneurons in striatal slices. However, it is important to point out that $\left[\mathrm{Cl}^{-}\right]_{\mathrm{i}}$ is not invariant. For example, $\left[\mathrm{Cl}^{-}\right]_{\mathrm{i}}$ is relatively high in neonatal neurons with low expression of KCC2 transporters (Rivera et al., 1999). In addition, although our experiments emphasized their activation by intracellular $\mathrm{Cl}^{-}$, Slo2. 1 is also $\mathrm{Na}^{+}$sensitive, and intracellular $\mathrm{Na}^{+}$and $\mathrm{Cl}^{-}$can increase in mature neurons as a result of firing activity (Fiumelli et al., 2005) or in response to ischemic conditions (Inglefield and Schwartz-Bloom, 1998). In this regard, striatal cholinergic interneurons are relatively spared during ischemia (Calabresi et al., 2000b), and if this is a result of Slo2.1 activation, cell viability might be further enhanced by interfering with the receptor-mediated channel inhibition that we have described. 


\section{Novel ion channel targets in striatal cholinergic interneurons} Striatal cholinergic tone is integral to basal ganglia function, and drugs that affect cholinergic transmission have proven therapeutic value in disorders of the basal ganglia [e.g., anti-cholinergics in Parkinson's disease (Duvoisin, 1967)]. Striatal ACh levels are determined by ongoing activity of cholinergic interneurons and their regulation by neuromodulatory mechanisms, such as those mediated by mGluR $1 / 5$ receptors. We have identified TrpC3/ TrpC7 and Slo2.1 as ion channel effectors that mediate downstream effects of mGluR $1 / 5$ receptors; within the striatum, these channels are selectively localized to cholinergic interneurons, providing novel potential therapeutic targets to alter tonic activity of striatal cholinergic interneurons or extrinsic neuromodulatory control over striatal cholinergic tone.

\section{References}

Annoura H, Fukunaga A, Uesugi M, Tatsuoka T, Horikawa Y (1996) A novel class of antagonists for metabotropic glutamate receptors, 7-(hydroxyimino)cyclopropa[b]chromen-1a-carboxylates. Bioorg Med Chem Lett 6:763-766.

Bell MI, Richardson PJ, Lee K (2000) Histamine depolarizes cholinergic interneurones in the rat striatum via a H1-receptor mediated action. Br J Pharmacol 131:1135-1142.

Bell MI, Richardson PJ, Lee K (2002) Functional and molecular characterization of metabotropic glutamate receptors expressed in rat striatal cholinergic interneurones. J Neurochem 81:142-149.

Bennett BD, Callaway JC, Wilson CJ (2000) Intrinsic membrane properties underlying spontaneous tonic firing in neostriatal cholinergic interneurons. J Neurosci 20:8493.

Berg AP, Bayliss DA (2007) Striatal cholinergic interneurons express a receptor-insensitive homomeric TASK-3-like background $\mathrm{K}^{+}$current. J Neurophysiol 97:1546-1552.

Bhattacharjee A, Kaczmarek LK (2005) For $\mathrm{K}^{+}$channels, $\mathrm{Na}^{+}$is the new $\mathrm{Ca}^{2+}$. Trends Neurosci 28:422-428.

Bhattacharjee A, Joiner WJ, Wu M, Yang Y, Sigworth FJ, Kaczmarek LK (2003) Slick (Slo2.1), a rapidly-gating sodium-activated potassium channel inhibited by ATP. J Neurosci 23:11681-11691.

Bonsi P, Cuomo D, De Persis C, Centonze D, Bernardi G, Calabresi P, Pisani A (2005) Modulatory action of metabotropic glutamate receptor (mGluR) 5 on mGluR1 function in striatal cholinergic interneurons. Neuropharmacology 49:104-113.

Calabresi P, Saiardi A, Pisani A, Baik JH, Centonze D, Mercuri NB, Bernardi G, Borrelli E (1997) Abnormal synaptic plasticity in the striatum of mice lacking dopamine $\mathrm{D}_{2}$ receptors. J Neurosci 17:4536-4544.

Calabresi P, Centonze D, Pisani A, Bernardi G (1999) Metabotropic glutamate receptors and cell-type-specific vulnerability in the striatum: implication for ischemia and Huntington's disease. Exp Neurol 158:97-108.

Calabresi P, Centonze D, Gubellini P, Pisani A, Bernardi G (2000a) Acetylcholine-mediated modulation of striatal function. Trends Neurosci 23:120-126.

Calabresi P, Centonze D, Bernardi G (2000b) Cellular factors controlling neuronal vulnerability in the brain: a lesson from the striatum. Neurology 55:1249-1255.

Centonze D, Gubellini P, Bernardi G, Calabresi P (1999) Permissive role of interneurons in corticostriatal synaptic plasticity. Brain Res Brain Res Rev 31:1-5.

Clapham DE (2003) TRP channels as cellular sensors. Nature 426:517-524.

Clapham DE, Runnels LW, Strubing C (2001) The TRP ion channel family. Nat Rev Neurosci 2:387-396.

Conn PJ, Pin JP (1997) Pharmacology and functions of metabotropic glutamate receptors. Annu Rev Pharmacol Toxicol 37:205-237.

Conn PJ, Battaglia G, Marino MJ, Nicoletti F (2005) Metabotropic glutamate receptors in the basal ganglia motor circuit. Nat Rev Neurosci 6:787-798.

Dietrich A, Schnitzler M, Kalwa H, Storch U, Gudermann T (2005) Functional characterization and physiological relevance of the TRPC3/6/7 subfamily of cation channels. Naunyn Schmiedebergs Arch Pharmacol 371:257-265.
Duvoisin RC (1967) Cholinergic-anticholinergic antagonism in parkinsonism. Arch Neurol 17:124-136.

Fiumelli H, Cancedda L, Poo MM (2005) Modulation of GABAergic transmission by activity via postsynaptic $\mathrm{Ca}^{2+}$-dependent regulation of $\mathrm{KCC} 2$ function. Neuron 48:773-786.

Gee CE, Benquet P, Gerber U (2003) Group I metabotropic glutamate receptors activate a calcium-sensitive transient receptor potential-like conductance in rat hippocampus. J Physiol (Lond) 546:655-664.

Geiser M, Cebe R, Drewello D, Schmitz R (2001) Integration of PCR fragments at any specific site within cloning vectors without the use of restriction enzymes and DNA ligase. Biotechniques 31:88-90:92.

Inglefield JR, Schwartz-Bloom RD (1998) Optical imaging of hippocampal neurons with a chloride-sensitive dye: early effects of in vitro ischemia. J Neurochem 70:2500-2509.

Inoue R, Okada T, Onoue H, Hara Y, Shimizu S, Naitoh S, Ito Y, Mori Y (2001) The transient receptor potential protein homologue TRP6 is the essential component of vascular $\alpha 1$-adrenoceptor-activated $\mathrm{Ca}^{2+}$ permeable cation channel. Circ Res 88:325-332.

Kawaguchi Y, Wilson CJ, Augood SJ, Emson PC (1995) Striatal interneurones: chemical, physiological and morphological characterization. Trends Neurosci 18:527-535.

Kim GD, Carr IC, Anderson LA, Zabavnik J, Eidne KA, Milligan G (1994) The long isoform of the rat thyrotropin-releasing hormone receptor down-regulates Gq proteins. J Biol Chem 269:19933-19940.

Kim SJ, Kim YS, Yuan JP, Petralia RS, Worley PF, Linden DJ (2003) Activation of the TRPC1 cation channel by metabotropic glutamate receptor mGluR1. Nature 426:285-291.

Kyrozis A, Reichling DB (1995) Perforated-patch recording with gramicidin avoids artifactual changes in intracellular chloride concentration. J Neurosci Methods 57:27-35.

Liman ER, Corey DP, Dulac C (1999) TRP2: a candidate transduction channel for mammalian pheromone sensory signaling. Proc Natl Acad Sci USA 96:5791-5796.

Mannaioni G, Marino MJ, Valenti O, Traynelis SF, Conn PJ (2001) Metabotropic glutamate receptors 1 and 5 differentially regulate CA1 pyramidal cell function. J Neurosci 21:5925-5934.

Marti M, Paganini F, Stocchi S, Bianchi C, Beani L, Morari M (2001) Presynaptic group I and II metabotropic glutamate receptors oppositely modulate striatal acetylcholine release. Eur J Neurosci 14:1181-1184.

Micheli F (2000) Methylphenylethynylpyridine (MPEP) Novartis. Curr Opin Investig Drugs 1:355-359.

Munakata M, Akaike N (1994) Regulation of $\mathrm{K}^{+}$conductance by histamine $\mathrm{H} 1$ and $\mathrm{H} 2$ receptors in neurones dissociated from rat neostriatum. J Physiol (Lond) 480:233-245.

Otsuka Y, Sakagami H, Owada Y, Kondo H (1998) Differential localization of mRNAs for mammalian trps, presumptive capacitative calcium entry channels, in the adult mouse brain. Tohoku J Exp Med 185:139-146.

Pintor A, Potenza RL, Domenici MR, Tiburzi F, Reggio R, Pezzola A, Popoli P (2000) Age-related decline in the functional response of striatal group I mGlu receptors. NeuroReport 11:3033-3038.

Pisani A, Bonsi P, Centonze D, Bernardi G, Calabresi P (2001) Functional coexpression of excitatory mGluR1 and mGluR5 on striatal cholinergic interneurons. Neuropharmacology 40:460-463.

Rivera C, Voipio J, Payne JA, Ruusuvuori E, Lahtinen H, Lamsa K, Pirvola U, Saarma M, Kaila K (1999) The $\mathrm{K}^{+} / \mathrm{Cl}^{-}$co-transporter KCC2 renders GABA hyperpolarizing during neuronal maturation. Nature 397:251-255.

Santi CM, Ferreira G, Yang B, Gazula VR, Butler A, Wei A, Kaczmarek LK, Salkoff L (2006) Opposite regulation of Slick and Slack $\mathrm{K}^{+}$channels by neuromodulators. J Neurosci 26:5059-5068.

Schaefer M, Plant TD, Obukhov AG, Hofmann T, Gudermann T, Schultz G (2000) Receptor-mediated regulation of the nonselective cation channels TRPC4 and TRPC5. J Biol Chem 275:17517-17526.

Song WJ, Tkatch T, Baranauskas G, Ichinohe N, Kitai ST, Surmeier DJ (1998) Somatodendritic depolarization-activated potassium currents in rat neostriatal cholinergic interneurons are predominantly of the A type and attributable to coexpression of Kv4.2 and Kv4.1 subunits. J Neurosci 18:3124-3137.

Strubing C, Krapivinsky G, Krapivinsky L, Clapham DE (2001) TRPC1 and 
TRPC5 form a novel cation channel in mammalian brain. Neuron 29:645-655.

Takeshita Y, Harata N, Akaike N (1996) Suppression of $\mathrm{K}^{+}$conductance by metabotropic glutamate receptor in acutely dissociated large cholinergicneurons of rat caudate putamen. J Neurophysiol 76:1545-1558.

Tallaksen-Greene SJ, Kaatz KW, Romano C, Albin RL (1998) Localization of mGluRla-like immunoreactivity and mGluR5-like immunoreactivity in identified populations of striatal neurons. Brain Res 780:210-217.

Talley EM, Solorzano G, Lei Q, Kim D, Bayliss DA (2001) CNS distribution of members of the two-pore-domain (KCNK) potassium channel family. J Neurosci 21:7491-7505.

Trebak M, Lemonnier L, Smyth JT, Vazquez G, Putney Jr JW (2007) Phos- pholipase C-coupled receptors and activation of TRPC channels. Handb Exp Pharmacol 593-614.

Wang Z, Kai L, Day M, Ronesi J, Yin HH, Ding J, Tkatch T, Lovinger DM, Surmeier DJ (2006) Dopaminergic control of corticostriatal long-term synaptic depression in medium spiny neurons is mediated by cholinergic interneurons. Neuron 50:443-452.

Wilson CJ (2005) The mechanism of intrinsic amplification of hyperpolarizations and spontaneous bursting in striatal cholinergic interneurons. Neuron 45:575-585.

Wu M, Hajszan T, Xu C, Leranth C, Alreja M (2004) Group I metabotropic glutamate receptor activation produces a direct excitation of identified septohippocampal cholinergic neurons. J Neurophysiol 92: 1216-1225. 